\title{
QUANTITATIVE Toxoplasma gondii OOCYST DETECTION BY A MODIFIED KATO KATZ TEST USING KINYOUN STAINING (KKK) IN ME49 STRAIN EXPERIMENTALLY INFECTED CATS
}

\author{
Luciana Regina MEIRELES(1), Vinícius Suehiro TSUTSUI(1), Claudia Villano do CARMO(2), Andrés Jimenez GALISTEO Jr.(3), Roberto Mitsuyoshi HIRAMOTO(4), \\ Henrique César Katsumi TERENTOWICZ(1) \& Heitor Franco de ANDRADE JÚNIOR(1)
}

\begin{abstract}
SUMMARY
We detected Toxoplasma gondii oocysts in feces of experimentally infected cats, using a Kato Katz approach with subsequent Kinyoun staining. Animals serologically negative to $T$. gondii were infected orally with $5 \times 10^{2}$ mice brain cysts of ME49 strain. Feces were collected daily from the $3^{\text {rd }}$ to the $30^{\text {th }}$ day after challenge. Oocysts were detected by qualitative sugar flotation and the quantitative modified Kato Katz stained by Kinyoun (KKK). In the experimentally infected cats, oocysts were detected from the $7^{\text {th }}$ to $15^{\text {th }}$ day through sugar flotation technique, but oocysts were found in KKK from the $6^{\text {th }}$ to $16^{\text {th }}$ day, being sensitive for a larger period, with permanent documentation. The peak of oocysts excretion occurred between the $8^{\text {th }}$ to $11^{\text {th }}$ days after challenge, before any serological positive result. KKK could be used in the screening and quantification of oocysts excretion in feces of suspected animals, with reduced handling of infective material, decreasing the possibility of environmental and operator contamination.
\end{abstract}

KEYWORDS: Toxoplasma gondii; Kato Katz; Kinyoun; Oocysts; Cat; Diagnosis.

\section{INTRODUCTION}

Humans become infected with Toxoplasma gondii mainly by ingesting uncooked meat containing viable tissue cysts or by ingesting food or water contaminated with oocysts from the feces of infected cats (DUBEY \& BEATTIE, 1988). T. gondii oocysts are shed in large numbers by domestic cats and other members of the Felidae after ingesting prey or contaminated water (HILL \& DUBEY, 2002). These oocysts mature in the environment and are disseminated through rain and surface water, resulting in widespread contamination of the environment (DUBEY \& FRENKEL, 1972; DUBEY, 2001). Kittens are probably the major source of contamination as they are common and produce large numbers of oocysts (DUBEY \& CARPENTER, 1993).

Waterborne outbreaks of acute toxoplasmosis worldwide reinforce the transmission of $T$. gondii to humans through water contaminated with oocysts and may have a greater epidemiological impact than previously believed (DUBEY \& CARPENTER, 1993; KARANIS et al., 2007). Findings regarding the prevalence of Toxoplasma oocysts in water are still rare and difficult (BOWIE et al., 1997; ISAACRENTON et al., 1998; DE MOURA et al., 2006). Recently, new alternative methods have been proposed, but they involve numerous centrifuging and expensive reagents with molecular detection of Toxoplasma DNA (DUMETRE \& DARDE, 2004; KOURENTI \& KARANIS, 2006). For epidemiologic surveys, seroprevalence in cats allows indirect estimation and are more feasible than oocyst fecal examination, providing an indicator of environmental contamination (MEIRELES et al., 2004). Ooccysts can be detected by examination of cat feces by concentration methods such as flotation in high-density sucrose solution, with risk of environmental and operator contamination due to extensive manipulation (DUBEY, 2004). Routine Cryptosporidium oocysts isolation in human feces uses a rapid modified-acid method, Kinyoun stain (AMATO NETO et al., 1996), which allows clear identification of the infection with minimum of stool manipulation, but without quantification, which is a feature of the Kato-Katz test (KATZ et al., 1972). We studied oocysts excretion in feces of experimentally infected cats by a combination of these methods, by Kinyoun staining of a thick quantitative smear after KatoKatz, for detection and quantification.

\section{MATERIAL AND METHODS}

For experimental cat infection, recently weaned cats were fed with $5 \times 10^{2}$ cysts of ME-49 strain of $T$. gondii obtained from brains of previously inbred mice (HIRAMOTO et al., 2002). The animals were maintained at the Institute of Tropical Medicine of São Paulo University, receiving commercial food and water ad libitum and their feces were daily collected to the $30^{\text {th }}$ day post-challenge, with weekly bleeding under anesthesia. The cats were isolated and manipulated before or during the infection according to 'Principles of Laboratory Animal Care' (CLARK, 1996). Feces were examined daily by two methods.

(1) Instituto de Medicina Tropical de São Paulo, São Paulo, SP, Brasil.

(2) Instituto Butantan, São Paulo, SP, Brasil.

(3) Instituto de Pesquisas Energéticas e Nucleares, São Paulo, SP, Brasil.

(4) Instituto Adolfo Lutz, São Paulo, SP, Brasil.

Correspondence to: Heitor Franco de Andrade Jr, Av. Dr. Enéas de Carvalho Aguiar 470, 05403-000 São Paulo, SP, Brasil. E-mail: hfandrad@usp.br 


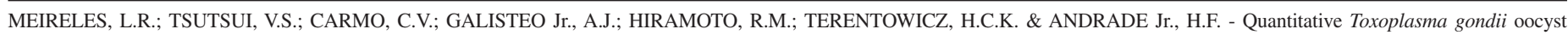
detection by a modified Kato Katz test using Kinyoun staining (KKK) in ME49 strain experimentally infected cats. Rev. Inst. Med. trop. S. Paulo, 50(3): 187-190, 2008.

Sugar flotation technique (SHEATHER, 1923) was performed in $5 \mathrm{~g}$ of feces mixed with $45 \mathrm{~mL}$ of a sugar solution (density 1.208) and centrifuged at $1,000 \mathrm{~g}$ for 10 minutes, and the surface film transferred to a slide. Oocyst search was performed by two independent observers, looking for $10 \mu \mathrm{m}$ thick walled structures, containing cellular structures, as there is no maturation to sporozoites at this stage.

Feces were also processed by a modified Kato Katz stool collection, with subsequent Kinyoun staining (KKK). Briefly, a small amount of fecal material was placed on scrap paper and a piece of nylon sieve was pressed on top of it so that some of the feces sieved through the screen and accumulated on top of the 180 mesh nylon sieve. A spatula was scraped across the upper surface of the screen to collect the sieved feces. The spatula was used to deposit the feces in the orifice of the perforated plate on a microscope slide. The perpendicular 4x10x1 mm orifice was devised to contain exactly $0.04 \mathrm{~g}$ or $40 \mu \mathrm{L}$ of feces, at one corner of the slide. The other side of the spatula was passed over a nylon sieve and over the perforated plate to remove excess feces. The plate was carefully removed by lifting, leaving behind a small square mould of sieved material. Opposite corner of other microscope slide was pressed on top of this, and a relatively thin smear was obtained by sliding over the slides in order to provide a thick smear in each slide. The material was air dried, heated and stained by Kinyoun method as described elsewhere (AMATO NETO et al., 1996), with subsequent mounting. T.gondii oocysts appeared as red cystic structures with 10 $\mu \mathrm{m}$ diameter, with preservation of internal details. Oocyst frequency in the preparation was determined both by using a quick semiquantitative method, scoring as (-) when no oocysts were found, (+) when at least one stained oocyst was found in the slide; $(++)$ when rare stained oocysts were found in the slide but not in every field; (+++) when at least one stained oocyst was found in each 20X optical field and $(++++)$ when more than one stained oocyst were found in each 20X optical field. This analysis was easily performed in only one of the KKK slides by two independent observers. Quantitative determination was performed in both slides from each preparation for determination of total numbers of oocysts by two independent observers and the oocysts number per gram of feces determined assuming that the whole preparation in the two slides had $0.04 \mathrm{~g}$ of feces.

Serum specific anti $T$. gondii IgG was determined in weekly collected serum samples by a conventional ELISA, using microplate coated with saline extract from RH strain tachyzoites as elsewhere described (MEIRELES et al., 2004) and expressed as titer, the inverse dilution of sera that gives 1.0 O.D. over control in the ELISA assay.

\section{RESULTS}

Oocyst identification by both methods is demonstrated in Fig. 1. Sucrose flotation allows demonstration of cystic structures, with 10 $\mu \mathrm{m}$ diameter clearly identified by contract phase microscopy, as shown in Fig. 1A. The Kato-Katz-Kinyoun (KKK) shows a clearly identified red structure, over a background of fecal contents, without any other acid fast stained structure, as could be seen in Fig. 1B, allowing also both identification and quantification.

Detection of $T$. gondii oocysts in the stools of four experimentally infected cats (two males and two females) fed with ME-49 T. gondii strains is shown in Fig. 2, associated to specific IgG titres. Oocysts

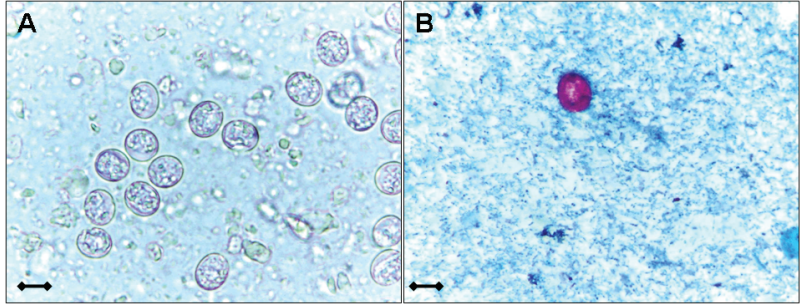

Fig. 1 - Representative images from stool detection of $T$. gondii immature oocysts. A - T. gondii oocysts in sucrose solution suspension. B - T. gondii oocyst stained by KKK. Bar $=10 \mu \mathrm{m}$.

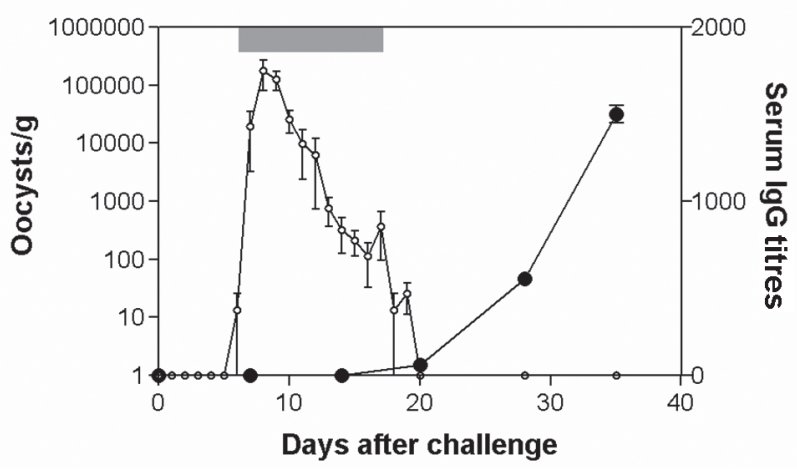

Fig. 2 - Quantitative mean oocyst excretion in cats experimentally infected with $T$. gondii ME-49 strain. Open dots: oocyst/g stools by KKK. Closed dots: mean anti $T$. gondii IgG antibody titres by ELISA. Shaded bar: period of oocyst detection by sucrose flotation. Bars represent SEM (Standard error of mean).

were detected from the $7^{\text {th }}$ to $15^{\text {th }}$ day through flotation technique, but KKK allowed detection of oocysts from the $6^{\text {th }}$ to $16^{\text {th }}$ day, with permanent documentation. Antibody titers were found in sera only after the declining of oocyst excretion which completely disappears after the $17^{\text {th }}$ day of challenge in all animals. The excretion was absent after this period until the $30^{\text {th }}$ day after challenge.

Oocyst excretion in individual animals are shown in Fig. 3, compared to KKK semi-quantitative estimation of oocysts, showing that the peak of excretion occurred in the $8^{\text {th }}$ to $11^{\text {th }}$ days after challenge in all individual animals. Quantitative analysis shows an early acute peak in all animals, with subsequent relatively slow decline, with an asymmetric profile, by both quantitative and semi-quantitative data. The oocyst excretion was very similar in all animals, with all cats showing at least one day with $>10^{5}$ oocysts/gram of feces. There is a very good association between the semi-quantitative scoring in one slide and the quantitative data, allowing the use of this quick scoring system in the screening of samples for posterior study.

\section{DISCUSSION}

Toxoplasma oocysts identification is easily performed with our modification of Kato-Katz direct fecal examination test, allowing quick identification of the presence of oocyst with little equipment. Oocyst preservation in KKK also allows gross genera identification, due to the preservation of oocyst diameter, but more accurate studies other than morphology must be performed for adequate speciation, as elsewhere described (SHARES et al., 2005). Without staining, the dried 

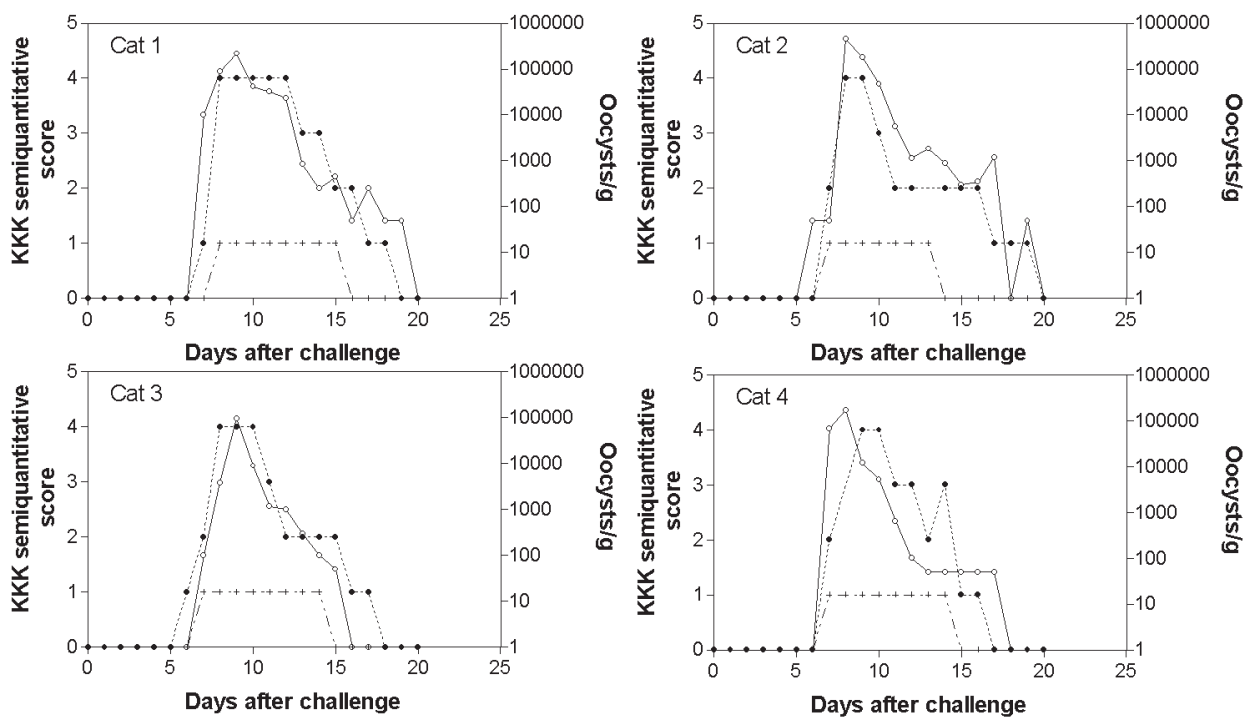

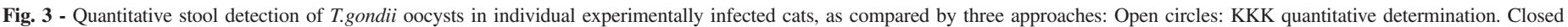
circles $=$ KKK semi-quantitative scoring. Dashed line $=$ sucrose flotation findings $(0=$ negative $+=$ positive $)$.

slide could be an alternative for nucleic acid preservation for genomic speciation, which could be performed by nucleic acid purification and adequate primers in PCR (SALANT et al., 2007).

KKK involves few steps of manipulation of infective material, decreasing the possibility of environmental and operator contamination, destroying all viability of the oocysts. The sugar flotation technique has the disadvantage of multiple steps with infective material manipulation and centrifugation, increasing the risk of contamination. KKK also allow quantitative data to be read easily in field conditions, or transported without preservation due to the stable documentation, without new steps required for quantitative determination with sugar flotation. Other advantages of KKK include the small amount of feces required to perform the test as well as the low cost of the technique, together with its suitability for rapid use under field conditions, as the veterinary office.

Oocyst excretion in stools in our experimentally infected cats was short lived, with positive serology occurring after the main excretion of oocysts. These findings were reported elsewhere, despite some descriptions of persistent excretion in some models, ascribed to strains or parasite variation (DUBEY, 2005). Specific IgG serology only becomes evident after oocyst excretion, which results in poor diagnostic value for individual felids that are implicated as a source of $T$. gondii spreading, but it is a feasible technique for feline toxoplasmosis prevalence, with results related to a past excretion of oocysts and chronic infection (MEIRELES et al., 2004, SALANT et al., 2007).

Morphological approaches on Toxoplasma oocysts identification have been neglected in recent years, due to the upsurge of more precise technologies, but could be also useful for veterinary practice, for diagnosis or screening sick animals. We suggest that this modified technique could be introduced for screening and detection of oocyst excretion in feces of suspected animals, both in epidemiological and clinical studies.

\section{RESUMO}

Deteç̧ão quantitativa de oocistos de Toxoplasma gondii, por um teste modificado de Kato Katz usando coloração de Kinyoun (KKK), em gatos infectados experimentalmente com a cepa ME49

Detectamos oocistos de Toxoplasma gondii em fezes de gatos experimentalmente infectados, usando a abordagem de Kato Katz, com subseqüente coloração pelo método de Kinyoun. Animais sorologicamente negativos ao T. gondii foram infectados por via oral com $5 \times 10^{2}$ cistos da cepa ME49 de cérebros de camundongos. Fezes foram colhidas diariamente a partir do $3^{\circ}$ até o $30^{\circ}$ dia pós-infecção. Oocistos foram detectados por centrífugo-flutuação em sacarose qualitativa e pelo método quantitativo de Kato Katz modificado corado pela técnica de Kinyoun (KKK). Em gatos experimentalmente infectados, oocistos foram detectados do $7^{\circ}$ ao $15^{\circ}$ dia pela técnica de centrífugo-flutuação em sacarose, mas oocistos foram detectados do $6^{\circ}$ ao $16^{\circ}$ dia pelo KKK, sendo sensível por um período maior, com documentação permanente. O pico da excreção de oocistos ocorreu entre $8^{\circ}$ a $11^{\circ}$ dia pós-infecção, antes de resultado sorológico positivo. KKK pode ser utilizado na triagem e quantificação da excreção de oocistos em fezes de animais suspeitos, com redução da manipulação de material infectante, diminuindo a possibilidade de contaminação ambiental e do operador.

\section{ACKNOWLEDGEMENTS}

We gratefully thank the skilled technical assistance of Roselaine Pereira Alvim Cardoso. This work was supported by LIMHCFMUSP49, CAPES and CNPQ. 


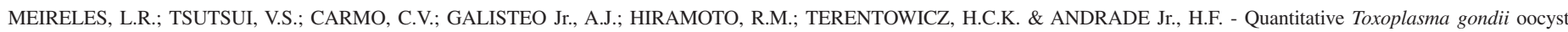
detection by a modified Kato Katz test using Kinyoun staining (KKK) in ME49 strain experimentally infected cats. Rev. Inst. Med. trop. S. Paulo, 50(3): 187-190, 2008.

\section{REFERENCES}

1. AMATO NETO, V.; BRAZ, L.M.A.; DI PIETRO, A.O. \& MODOLO, J.R. - Pesquisa de oocistos de Cryptosporidium sp em fezes: comparação entre os métodos de Kinyoun modificado e de Heine. Rev. Soc. bras. Med. trop., 29: 575-578, 1996.

2. BOWIE, W.R.; KING, A.S.; WERKER, D.H. et al. - Outbreak of toxoplasmosis associated with municipal drinking water. Lancet, 350: 173-177, 1997.

3. CLARK, J.D. - Guide for the care and use of laboratory animals. Institute of Laboratory Animal Resources Commission on Life Sciences. National Research Council. Washington, National Academy Press, 1996.

4. DE MOURA, L.; BAHIA-OLIVEIRA, L.M.G.; WADA, M.Y. et al. - Waterborne toxoplasmosis, Brazil, from field to gene. Emerg. infect. Dis., 12: 326-329, 2006.

5. DUBEY, J.P. \& BEATTIE, C.P. - Toxoplasmosis of animals and man. Boca Raton, CRC Press, 1988.

6. DUBEY, J.P. \& CARPENTER, J.L. - Neonatal toxoplasmosis in littermate cats. J. Amer. vet. med. Ass., 203: 1546-1549, 1993.

7. DUBEY, J.P. \& FRENKEL, J.K. - Cyst-induced toxoplasmosis in cats. J. Protozool., 19: $155-177,1972$.

8. DUBEY, J.P. - Oocyst shedding by cats fed isolated bradyzoites and comparison of infectivity of bradyzoites of the VEG strain Toxoplasma gondii to cats and mice. J. Parasit., 87: 215-219, 2001.

9. DUBEY, J.P. - Toxoplasmosis - a waterborne zoonosis. Vet. Parasit., 126: 57-72, 2004.

10. DUBEY, J.P. - Unexpected oocyst shedding by cats fed Toxoplasma gondii tachyzoites: in vivo stage conversion and strain variation. Vet. Parasit., 133: 289-298, 2005.

11. DUMETRE, A. \& DARDE, M.L. - Purification of Toxoplasma gondii oocysts by cesium chloride gradient. J. microbiol. Meth., 56: 427-430, 2004.

12. HILL, D. \& DUBEY, J.P. - Toxoplasma gondii: transmission, diagnosis and prevention. Clin. Microbiol. Infect., 8: 634-640, 2002.
13. HIRAMOTO, R.M.; GALISTEO Jr., A.J.; NASCIMENTO, N. \& ANDRADE Jr., H.F. 200 Gy sterilised Toxoplasma gondii tachyzoites maintain metabolic functions and mammalian cell invasion, eliciting cellular immunity and cytokine response similar to natural infection in mice. Vaccine, 20: 2072-2081, 2002.

14. ISAAC-RENTON, J.; BOWIE, W.R.; KING, A. et al. - Detection of Toxoplasma gondii oocysts in drinking water. Appl. environm. Microbiol., 64: 2278-2280, 1998.

15. KATZ, N.; CHAVES, A. \& PELLEGRINO, J. - A simple device for quantitative stool thick-smear technique in schistosomiasis mansoni. Rev. Inst. Med. trop. S. Paulo, 14: 397-400, 1972.

16. KARANIS, P.; KOURENTI, C. \& SMITH, H. - Waterborne transmission of protozoan parasites: a worldwide review of outbreaks and lessons learnt. J. Water Hlth., 5: 1$38,2007$.

17. KOURENTI, C. \& KARANIS, P. - Evaluation and applicability of a purification method coupled with nested PCR for the detection of Toxoplasma oocysts in water. Lett. appl. Microbiol., 43: 475-481, 2006.

18. MEIRELES, L.R.; GALISTEO Jr., A.J.; POMPEU, E. \& ANDRADE Jr., H.F. Toxoplasma gondii spreading in an urban area evaluated by seroprevalence in freeliving cats and dogs. Trop. Med. int. Hlth., 9: 876-881, 2004.

19. SALANT, H.; MARKOVICS, A.; SPIRA, D.T. \& HAMBURGER, J. - The development of a molecular approach for coprodiagnosis of Toxoplasma gondii. Vet. Parasit., 146: $214-220,2007$

20. SCHARES, G.; PANTCHEV, N.; BARUTZKI, D. et al. - Oocysts of Neospora caninum Hammondia heydorni, Toxoplasma gondii and Hammondia hammondi in faeces collected from dogs in Germany. Int. J. Parasit., 35: 1525-1537, 2005.

21. SHEATHER, A.L. - The detection of intestinal protozoa and mange parasites by a flotation technique. J. comp. Path. Therap., 36: 266-275, 1923.

Received: 4 December 2007

Accepted: 7 April 2008 